\title{
In vitro Antibacterial Effect of $2 \%$ Chlorhexidine Against Enterococcus faecalis in Dentin Previously Irrigated with $5 \%$ Sodium Hypochlorite
}

\author{
Efecto Antibacterial in vitro de Clorhexidina 2\% contra Enterococcus faecalis \\ en Dentina Irrigada Previamente con Hipoclorito de Sodio $5 \%$
}

\author{
Diego Echeverri* \& Daniela Alderete ${ }^{* *}$
}

ECHEVERRI, D. \& ALDERETE, D. In vitro antibacterial effect of $2 \%$ chlorhexidine against Enterococcus faecalis in dentin previously irrigated with 5\% sodium hypochlorite. Int. J. Odontostomat., 9(1):25-29, 2015.

ABSTRACT: The aim of this study was to observe whether the antibacterial effect of $2 \%$ chlorhexidine against Enterococcus faecalis in dentine is altered by previous irrigation with $5 \%$ sodium hypochlorite. Dentin discs were prepared with different irrigation protocols: group 1, immersed in 2\% CHX for 25 min; group 2 immersed in $5 \% \mathrm{NaOCl}$ for 25 minutes; group 3, immersed in $5 \% \mathrm{NaOCl}$, dried and irrigated with $3 \mathrm{ml}$ of $2 \% \mathrm{CHX}$; group 4 and 5 immersed in $5 \% \mathrm{NaOCl}$, rinsed with 5 and $25 \mathrm{ml}$ of distilled water respectively, dried and irrigated with $2 \% \mathrm{CHX}$. Group 6 , immersed in $0.9 \%$ sodium chloride. Discs were then placed in agar plates in which $E$. faecalis was grown and the inhibition zone around each disc was measured after 24 hours of incubation at $37^{\circ} \mathrm{C}$. All experimental groups showed E. faecalis growth inhibition. The most effective irrigant was $2 \% \mathrm{CHX}(\mathrm{P}<0.05)$. Groups in which both $\mathrm{NaOCl}$ and $\mathrm{CHX}$ were used displayed significantly smaller inhibition halos as compared with $2 \% \mathrm{CHX}$. Different volumes of water for rinsing did not cause significant improvement in growth inhibition. The antimicrobial effect of $2 \%$ chlorhexidine against $E$. faecalis was significantly reduced when dentin was previously irrigated with $5 \%$ sodium hypochlorite despite of rinsing with different volumes of water.

KEY WORDS: chlorhexidine digluconate, sodium hypochlorite, irrigant combination, Enterococcus faecalis.

\section{INTRODUCTION}

The presence of microorganisms and their byproducts within the root canal system is the main cause of pulpal and periapical disease (Dametto et al., 2005). There are many microbes associated to the development of periradicular lesions being one of the more studied Enterococcus faecalis (Stuart et al., 2006). E. faecalis is a Gram positive coccus from $D$ group, facultative anaerobic (Denotti et al., 2009) and possess several defense mechanisms that allow it to survive the effect of intracanal irrigants and medication (Stuart et al.).

One of the main objectives to achieve during endodontic therapy is reducing the amount of microorganisms from infected root canals (Vianna et al., 2009). In the pursuit of this goal it is imperative the elimination of necrotic tissue and infected debris by irrigation and instrumentation.
A series of irrigant solutions have been accepted for use in endodontic therapy. The action mechanism can be both mechanical, by dragging debris out of the root canal, or chemical through dissolution of necrotic tissue and dentin detoxification (El Karim et al., 2007). The ideal irrigant is one that shows antimicrobial activity, soft tissue dissolving capacity and smear layer removal without toxic side effects (Oliveira et al., 2006). Unfortunately, to date such irrigant does not exist, making it therefore necessary to combine or alternate different irrigant solutions to fulfill clinical needs.

Among irrigants available sodium hypochlorite $(\mathrm{NaOCl})$ has been accepted as the main irrigant during root canal treatment for decades (Byström \& Sandqvist, 1983; Vienna et al., 2004), being used at different concentrations (from $0.5 \%$ up to $5.25 \%$ or higher) and

\footnotetext{
* Adjunct Professor. School of Dentistry. Universidad Austral de Chile, Valdivia, Chile.

" Student. School of Dentistry. Universidad Austral de Chile, Valdivia, Chile.
} 
its main property is the ability of dissolving organic tissue (Mohammadi \& Abott, 2009). $\mathrm{NaOCl}$ is effective in killing bacteria, spores, yeast and virus in vitro (EI Karim et al.). However, E. faecalis can survive the action of sodium hypochlorite at low concentrations (Mohammadi \& Abott). The main disadvantage of $\mathrm{NaOCl}$ is its toxicity for periradicular tissues once it goes beyond the limits of the root canal, or when it accidentally makes contact with oral mucosa causing pain and severe inflammation associated with tissue destruction (Oliveira et al.).

In an effort to bypass $\mathrm{NaOCl}^{\prime}$ s adverse effects bearing in mind its limitations, the use of other irrigant solutions has been proposed. One of the more popular complementary irrigation agents is chlorhexidine (CHX) (Dametto et al.). Chlorhexidine digluconate is a substance widely used as oral rinse for prevention and treatment of periodontal disease and caries (Oliveira et al.). Its main characteristics are the wide spectrum antimicrobial effect, sustantivity, and relative low toxicity (Sassone et al., 2008). As well as $\mathrm{NaOCl}$, $\mathrm{CHX}$ has been used in several concentrations providing bacteriostatical or bactericidal effect depending on the microorganism sensitivity (Mohammed \& Abott).

Chlorhexidine is unable of dissolving organic tissue. For this reason it is not recommended to be used as single irrigant during endodontic therapy. Although it seems reasonable to use both irrigant solutions $(\mathrm{NaOCl}$ and $\mathrm{CHX})$ to maximize the benefits of each irrigant alone, it has been demonstrated that the combination of them will cause a chemical reaction that results in the formation of a precipitate (Parachloroaniline PCA) with low antimicrobial properties, as well as toxicity, potential staining of tooth structure and it also interferes with adaptation of root canal filling materials to dentin. Therefore, their combination inside the root canal should be avoided (Basrani et al., 2007; Marchesan et al., 2007; Mohammadi \& Abbott).

Antibiogram testing allows evaluation of the sensitivity of microorganisms to different antibiotic agents. Impregnating sensitivity discs with the testing agent on the culture media causes a halo of microbial growth inhibition. The size of this halo shows how effective is the tested agent. Given that sensitivity of microorganisms to chlorhexidin depends on its concentration, using dentin to create sensitivity discs could allow observation as to whether its effect changes with a previous $\mathrm{NaOCl}$ irrigation.
Thus, the objective of this in vitro study is to observe the antibacterial effect of $2 \% \mathrm{CHX}$ on $E$. faecalis in dentine with and without previous $\mathrm{NaOCl}$ irrigation using antibiogram testing.

\section{MATERIAL AND METHOD}

For the purpose of this study, forty-five cariesfree third molars were collected from private practice dental offices in Valdivia, Chile and kept in methyl alcohol until their use. From these, ninety dentin discs (2.5 mm thick, $4.4 \mathrm{~mm}$ diameter) were cut off from the crown (roof of pulp camera) perpendicular to tooth axis with a low speed saw (Iso Met) and shaped with high speed water cooled cylindric burs. After cutting, discs were immersed in $10 \%$ etilendiaminotetracetic acid (EDTA) for 5 minutes, rinsed with distilled water and sterilized in autoclave at $134^{\circ} \mathrm{C}$ for $20 \mathrm{~min}$. Then left 20 min for air drying.

Discs were distributed in six groups, fifteen samples each:

Group 1= Immersed in 2\% CHX for 25 min and dried with absorbent paper.

Group 2= Immersed in 5\% $\mathrm{NaOCl}$ for $25 \mathrm{~min}$ and dried with absorbent paper.

Group 3= Immersed in 5\% $\mathrm{NaOCl}$, for $25 \mathrm{~min}$ and dried with absorbent paper; then irrigated with $3 \mathrm{ml}$ of $2 \% \mathrm{CHX}$.

Group 4= Immersed in 5\% NaOCl, irrigated with $5 \mathrm{ml}$ of distilled water, paper dried and then irrigated with $3 \mathrm{ml}$ of $2 \% \mathrm{CHX}$.

Group 5= Immersed in 5\% NaOCl, irrigated with 25 $\mathrm{ml}$ of distilled water, paper dried and then irrigated with $3 \mathrm{ml}$ of $2 \% \mathrm{CHX}$.

Group 6= Immersed in sterile saline $(\mathrm{NaCl} 0.9 \%)$ for $25 \mathrm{~min}$ and paper dried.

The irrigating solutions were $2 \%$ chlorhexidine digluconate without colorants (Salcobrand, Chile), 5\% sodium hypochlorite (Hertz), 10\% EDTA (Hertz) and $0.9 \%$ sodium chloride (Braun).

Agar Diffusion Method. The method of agar diffusion was used, the same manner as antibiogram testing, 
replacing sensitivity paper discs for dentin ones. An innocuous of $E$. faecalis (ATCC 29212) was prepared at turbidity of $0.5 \mathrm{McF}$ arland tube (equivalent to 1.5 $\mathrm{CFU} / \mathrm{ml}$ ) and seeded in $5 \%$ goat blood Muller Hinton agar plates.

Once seeded, prepared discs were placed on the plates ( 6 discs each) and incubated in aerobic environment at $37^{\circ} \mathrm{C}$ for $24 \mathrm{~h}$. After that the diameter of growth inhibition halo around each disc was measured.

For statistical analysis ANOVA test was used and Benferroni and Duncan post hoc.

\section{RESULTS}

All the samples from experimental groups showed bacterial growth inhibition around the dentin discs. The mean of measurements for each group are shown in Table I.

Control group (6) $(0.9 \% \mathrm{NaCl})$ did not affect the growth of $\mathrm{E}$. faecalis and no inhibition around the discs was seen.

A statistically significant superior antimicrobial effect was observed for the samples in group $1(2 \%$ $\mathrm{CHX}$ ) (Mean 18.4 $\pm 2.0 \mathrm{SD})(\mathrm{P}<0.05)$.

Groups 3, 4 and 5 showed more inhibition than

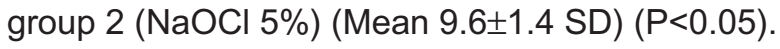

Among groups 3, 4 and 5, the biggest inhibition was observed for group $5(5 \% \mathrm{NaOCl}+25 \mathrm{ml} \mathrm{H} 20+$ $2 \% \mathrm{CHX}$ ) although the difference lacked statistical significance $(P>0.05)$.

\section{DISCUSSION}

The results obtained from this study show that both $\mathrm{NaOCl}$ and $\mathrm{CHX}$ in dentin discs can inhibit growth of $E$. faecalis on the culture plates being the last one significantly superior $(P<0.05)$. Dentin discs irrigated with both agents displayed minor inhibitory effect than that for $2 \% \mathrm{CHX}$ alone $(\mathrm{P}<0.05)$. Despite irrigation with different volumes of water in samples of groups 4 and 5 ( $5 \mathrm{ml}$ and $25 \mathrm{ml}$, respectively) after irrigation with $\mathrm{NaOCl}$, the antibacterial effect did not show a significant improvement as compared with group $3(5 \% \mathrm{NaOCl}+2 \% \mathrm{CHX})(\mathrm{P}>0.05)$ although group 5 showed more growth inhibition among them.

As soon as discs from group $3(\mathrm{NaOCl}$ and $\mathrm{CHX}$, no water rinse) where irrigated with $2 \% \mathrm{CHX}$, staining of dentine could be appreciated with intense brown-red color, as described in previous reports (Basrani et al.; Mohammadi \& Abbott; Marchesan et al.). In samples from groups 4 and 5 , despite water rinse, a change in dentin color could be observed although with less intensity. This change was more evident after the $24 \mathrm{~h}$ incubation period. This finding matches reports from Basrani et al., who showed PCA formation even at very low concentrations of both irrigants $(\mathrm{NaOCl}$ and $\mathrm{CHX})$ using $\mathrm{X}$-ray photon spectoscopy (XPS) and time-of-flight secondary ion mass Spectometry (TOF-SIMS).

Our study corroborates the findings of Ferraz et al. (2007) who demonstrated that $2 \%$ CHX inhibits bacterial growth more than $\mathrm{NaOCl}$ at different concentrations. Likewise, we confirm reports from Vianna et al. (2009) who showed that inhibition halo is smaller when $2 \% \mathrm{CHX}$ is combined with $\mathrm{NaOCl}$ at high concentrations.

Table I. Variation range and mean diameter of bacterial growth inhibition halo around dentin discs, in millimeters in the different groups.

\begin{tabular}{|c|c|c|c|}
\hline \multirow{2}{*}{ Irrigant Solution } & \multicolumn{3}{|c|}{ Bacterial Growth Inhibition } \\
\hline & Range & Mean (士SD) & P value \\
\hline $2 \% \mathrm{CHX}$ & $15-22$ & $18.4( \pm 2.0)$ & $\mathrm{a}$ \\
\hline $5 \% \mathrm{NaOCl}$ & $07-12$ & $9.6( \pm 1.4)$ & $\mathrm{b}$ \\
\hline $5 \% \mathrm{NaOCl}+2 \% \mathrm{CHX}$ & $13-22$ & $16.3( \pm 2.4)$ & c \\
\hline $5 \% \mathrm{NaOCl}+5 \mathrm{ml} \mathrm{H}{ }_{2} \mathrm{O}+2 \% \mathrm{CHX}$ & $13-19$ & $16.2( \pm 1.5)$ & c \\
\hline $5 \% \mathrm{NaOCl}+25 \mathrm{ml} \mathrm{H}{ }_{2} \mathrm{O}+2 \% \mathrm{CHX}$ & $13-20$ & $16.7( \pm 1.9)$ & c \\
\hline $0.9 \%$ Sodium Chloride & 0 & $00.0( \pm 0)$ & --- \\
\hline
\end{tabular}


These observations however, are in contrast with reports from Kuruvilla \& Kamath (1998) who found mayor antibacterial activity against $\mathrm{E}$. faecalis when compared $\mathrm{CHX}$ alone and combined with $\mathrm{NaOCl}$. It is important to understand that in their study they used $\mathrm{CHX}$ at a concentration of $0.2 \%$ for in vivo irrigation of root canals. At that concentration $\mathrm{CHX}$ may be ineffective to certain microorganisms because its effect is dose dependent (Mohammadi \& Abbott). Besides, being an in vivo study, the presence of exudate within the root canals could have further reduced $\mathrm{CHX}$ action.

The precipitate formed after combining $\mathrm{NaOCl}$ and $\mathrm{CHX}$ has been defined as parachloroaniline (PCA) or chlorhexidine chloride (Kuruvila \& Kamath; Bastani et al.; Vianna et al., 2009). According with the evidence available, such compound has lesser antimicrobial activity than high concentrated $\mathrm{CHX}$ (Ferraz et al.) and its presence inside the root canal might hamper the proper adaptation of endodontic filling (Mohammadi \& Abbott). Therefore, it has been recommended to avoid that $\mathrm{CHX}$ and $\mathrm{NaOCl}$ are combined inside the root canal. Bearing in mind that $\mathrm{NaOCl}$ is the main irrigant solution for root canal therapy (Byström \& Sundqvist) because of its proteolytic capacity, it has been suggested $\mathrm{CHX}$ to be a final irrigant after $\mathrm{NaOCl}$ has being rinsed out with serum or $\mathrm{H}_{2} \mathrm{O}$ irrigation (Zehnder, 2006).

The results obtained from our study show that given the physic characteristics of dentine (tubular, organic/inorganic collagen network) it is unlikely that $\mathrm{NaOCl}$ can be completely removed from root dentine by rinsing and washing, rendering the mixture of these irrigants unavoidable.

Findings from in vitro studies must be carefully interpreted and extrapolated to the clinical environment. Dentin discs used for our purposes were cut off from coronal dentine of healthy molars. The bigger amount of tubules, therefore, permeability of dentin is not the same as in the root canal walls where the capacity of absorbing irrigants could be minor. On the other side, it has been demonstrated (Hsieh et al., 2007) that irrigation of the apical third of root canals is limited for anatomic reasons and fluid exchange is limited to the access of the irrigation needle tip. This characteristic could favor the accidental combination of irrigants inside the root canal.

Additionally, sensitivity of microorganisms to antimicrobial agents in vitro is far greater than in vivo conditions. Inside the root canal microorganisms dis- play several mechanisms to increase resistance and survival. For this reason it is desirable to use irrigants in higher concentrations available to provide an acceptable antimicrobial effect which in light of our results might be unachievable during clinical conditions because of inconspicuous PCA formation.

Considering that combination of $\mathrm{NaOCl}$ and $\mathrm{CHX}$ could be unavoidable in clinical conditions, it would be interesting to further study the long-term effect of PCA in dentin.

\section{CONCLUSION}

Growth inhibition of Enterococcus faecalis observed around dentin discs irrigated with $2 \% \mathrm{CHX}$ was significantly reduced when dentine had been previously irrigated with $\mathrm{NaOCl}$ regardless of the volume of water used for washing.

\section{ACKNOWLEDGMENTS}

Professor Heriberto Fernandez Jaramillo, for his support and orientation.

ECHEVERRI, D. \& ALDERETE, D. Efecto antibacterial in vitro de clorhexidina $2 \%$ contra Enterococcus faecalis en dentina irrigada previamente con hipoclorito de sodio $5 \%$. Int. J. Odontostomat., 9(1):24-29, 2015.

RESUMEN: El objetivo de este estudio fue observar si el efecto antibacterial de clorhexidina $2 \%$ contra Enterococcus faecalis en dentina puede verse afectado por la irrigación previa con hipoclorito de sodio al $5 \%$.Se cortaron discos de dentina y fueron preparados de acuerdo a diferentes protocolos de irrigación: grupo 1, sumergidos en $\mathrm{CHX} 2 \%$ por 25 min; grupo 2, sumergidos en $\mathrm{NaOCl} 5 \%$ por 25 min; grupo 3 inmersos en $\mathrm{NaOCl} 5 \%$, secados y posteriormente irrigados con $3 \mathrm{ml}$ de $\mathrm{CHX} 2 \%$; grupos 4 y 5 inmersos en $\mathrm{NaOCl} 5 \%$ por 25 minutos, lavados con 5 y 25 $\mathrm{ml}$ de agua destilada respectivamente, secados e irrigados con $3 \mathrm{ml}$ de $\mathrm{CHX} 2 \%$. Grupo 6 inmersión en solución salina 25 min. Posteriormente, los discos fueron colocados en platos agar en los cuales creció $E$. faecalis y se midió el diámetro del halo de inhibición en torno a cada disco tras $24 \mathrm{~h}$ de incubación aeróbica a $37^{\circ} \mathrm{C}$. Todos los grupos experimentales mostraron inhibición de crecimiento de E. faecalis. El irrigante más efectivo fue $\mathrm{CHX} 2 \%(\mathrm{P}<0.05)$. Los grupos en los que se utilizó $\mathrm{CHX}$ y $\mathrm{NaOCl}$ mostraron inhibición significativamente inferior a la observada con $\mathrm{CHX}$ sola. El uso de diferentes volúmenes de agua para lavado de la den- 
tina no causó una mejoría significativa en el efecto antimicrobiano observado. El efecto antimicrobiano de la clorhexidina al $2 \%$ contra $E$. faecalis fue reducido significativamente cuando la dentina se irrigó inicialmente con hipoclorito de sodio $5 \%$ a pesar del lavado con diferentes volúmenes de agua.

PALABRAS CLAVE: digluconato de clorhexidina, hipoclorito de sodio, combinación de irrigantes, Enterococcus faecalis.

\section{REFERENCES}

Basrani, B. R.; Manek, S.; Sodhi, R. N.; Fillery, E. \& Manzur, A. Interaction between sodium hypochlorite and chlorhexidine gluconate. J. Endod., 33(8):966-9, 2007.

Byström, A. \& Sundqvist, G. Bacteriologic evaluation of the effect of 0.5 percent sodium hypochlorite in endodontic therapy. Oral Surg. Oral Med. Oral Pathol., 55(3):30712, 1983.

Dametto, F. R.; Ferraz, C. C.; Gomes, B. P.; Zaia, A. A.; Teixeira, F. B. \& de Souza-Filho, F. J. In vitro assessment of the immediate and prolonged antimicrobial action of chlorhexidine gel as an endodontic irrigant against Enterococcus faecalis. Oral Surg. Oral Med. Oral Pathol. Oral Radiol. Endod., 99(6):768-72, 2005.

Denotti, G.; Piga, R.; Montaldo, C.; Erriu, M.; Pilia, F.; Piras, A.; Luca, M. D. \& Orrù, G. In vitro evaluation of Enterococcus faecalis adhesion on various endodontic medicaments. Open Dent. J., 3:120-4, 2009.

El Karim, I.; Kennedy, J. \& Hussey, D. The antimicrobial effects of root canal irrigation and medication. Oral Surg. Oral Med. Oral Pathol. Oral Radiol. Endod., 103(4):5609, 2007.

Ferraz, C. C; Gomez, B. P; Zaia, A. A.; Teixeira, F. B. \& SouzaFilho, F. J. Comparative study of the antimicrobial efficacy of chlorhexidine gel, chlorhexidine solution and sodium hypochlorite as endodontic irrigants. Braz. Dent. J., 18(4):294-8, 2007.

Hsieh, Y. D.; Gau, C. H.; Kung Wu, S. F.; Shen, E. C.; Hsu, P. W. \& Fu, E. Dynamic Dynamic recording of irrigating fluid distribution in root canals using thermal image analysis. Int. Endod. J., 40(1):11-7, 2007.

Kuruvilla, J. R. \& Kamath, M. P. Antimicrobial activity of $2.5 \%$ sodium hypochlorite and $0.2 \%$ chlorhexidine gluconate separately and combined, as endodontic irrigants. J. Endod., 24(7):472-6, 1998.

Marchesan, M. A.; Pasternak Júnior, B.; Afonso, M. M.; Sousa-Neto, M. D. \& Paschoalato, C. Chemical analysis of the flocculate formed by the association of sodium hypochlorite and chlorhexidine. Oral Surg. Oral Med. Oral Pathol. Oral Radiol. Endod., 103(5):e103-5, 2007.

Mohammadi, Z. \& Abbott, P. V. The properties and applications of chlorhexidine in endodontics. Int. Endod. J., 42(4):288-302, 2009.

Oliveira, D. P.; Barbizam, J. V.; Trope, M. \& Teixeira, F. B. In vitro antibacterial efficacy of endodontic irrigants against Enterococcus faecalis. Oral Surg. Oral Med. Oral Pathol. Oral Radiol. Endod., 103(5):702-6, 2007.

Sassone, L. M.; Fidel, R. A.; Murad, C. F.; Fidel, S. R. \& Hirata, R. Jr. Antimicrobial activity of sodium hypochlorite and chlorhexidine by two different tests. Aust. Endod. J., 34(1):19-24, 2008.

Stuart, C. H.; Schwartz, S. A.; Beeson, T. J. \& Owatz, C. B Enterococcus faecalis: its role in root canal treatment failure and current concepts in retreatment. J. Endod., 32(2):93-8, 2006.

Vianna, M. E.; Gomes, B. P.; Berver, V. B.; Zaia, A. A.; Ferraz, C. C. \& de Souza-Filho, F. J. In vitro evaluation of the antimicrobial activity of chlorhexidine and sodium hypochlorite. Oral Surg. Oral Med. Oral Pathol. Oral Radiol. Endod., 97(1):79-84, 2004.

Vianna, M. E. \& Gomes, B. P. Efficacy of sodium hypochlorite combined with chlorhexidine against Enterococcus faecalis in vitro. Oral Surg. Oral Med. Oral Pathol. Oral Radiol. Endod., 107(4):585-9, 2009.

Zehnder, M. Root canal irrigants. J. Endod., 32(5):389-98, 2006.

Correspondence to:

Diego Echeverri, DDS

School of Dentistry

Universidad Austral de Chile

Luis Rudloff 1640

Valdivia

CHILE

Email: di_echeverri@yahoo.es

Received: 08-08-2014

Accepted: 24-12-2014 